\title{
Clinical management of achalasia: current state of the art
}

This article was published in the following Dove Press journal:

Clinical and Experimental Gastroenterology

4 April 2016

Number of times this article has been viewed

\author{
Joseph T Krill \\ Rishi D Naik \\ Michael F Vaezi \\ Division of Gastroenterology, \\ Hepatology, and Nutrition, Center for \\ Swallowing and Esophageal Disorders, \\ Vanderbilt University Medical Center, \\ Nashville, TN, USA
}

\begin{abstract}
Achalasia is a primary disorder of esophageal motility. It classically presents with dysphagia to both solids and liquids but may be accompanied by regurgitation and chest pain. The gold standard for the diagnosis of achalasia is esophageal motility testing with manometry, which often reveals aperistalsis of the esophageal body and incomplete lower esophageal sphincter relaxation. The diagnosis is aided by complimentary tests, such as esophagogastroduodenoscopy and contrast radiography. Esophagogastroduodenoscopy is indicated to rule out mimickers of the disease known as "pseudoachalasia" (eg, malignancy). Endoscopic appearance of a dilated esophagus with retained food or saliva and a puckered lower esophageal sphincter should raise suspicion for achalasia. Additionally, barium esophagography may reveal a dilated esophagus with a distal tapering giving it a "bird's beak" appearance. Multiple therapeutic modalities aid in the management of achalasia, the decision of which depends on operative risk factors. Conventional treatments include medical therapy, botulinum toxin injection, pneumatic dilation, and Heller myotomy. The last two are defined as the most definitive treatment options. New emerging therapies include peroral endoscopic myotomy, placement of self-expanding metallic stents, and endoscopic sclerotherapy.
\end{abstract}

Keywords: achalasia, pseudoachalasia, pneumatic dilation, Heller myotomy, botulinum toxin injection, peroral endoscopic myotomy

\section{Introduction}

Achalasia, a primary esophageal motility disorder, is classically characterized by impaired relaxation of the lower esophageal sphincter (LES) and loss of esophageal peristalsis. ${ }^{1}$ The primary pathophysiologic disturbance is the loss of inhibitory interneurons in the myenteric plexus that are involved in facilitating LES relaxation for gastric accommodation of food boluses. ${ }^{2}$ Consequently, the classic symptomatic presentation involves dysphagia to both solids and liquids associated with regurgitation of undigested food. Further associated symptoms include substernal chest pain with dysphagia, weight loss, and dyspepsia that often leads to a misdiagnosis of gastroesophageal reflux disease. ${ }^{3,4}$ The incidence of achalasia is one in 100,000 individuals annually with a prevalence of ten in 10,000. It occurs equally among women and men and is without racial predilection. The peak incidence is between 30 and 60 years of age. ${ }^{5,6}$

Various diagnostic modalities have been implemented that assist in the diagnosis of achalasia. It is characterized on radiographic barium swallow by aperistalsis resulting in poor emptying of barium, esophageal dilation, and minimal LES opening, resulting in a tapering of the barium column giving it a "bird's beak" appearance (Figure 1A). Endoscopically, it is characterized by a dilated esophagus with retained 
saliva, undigested food particles, and liquid in the absence of attributing strictures or tumors (Figure 1B). Occasionally, patients are found to have a dilated esophagus when undergoing computed tomography of the chest (Figure 1C). Manometrically, it is characterized by incomplete relaxation of the LES and aperistalsis of the esophageal body (Figure 1D). ${ }^{1}$

The options for treatment of achalasia are vast with many new emerging therapies. Although no current treatment option is a definitive cure, the aim is to reduce the hypertonicity of the LES in an effort to relieve symptoms, improve esophageal emptying, and prevent further esophageal dilation. ${ }^{1}$ This is attempted via pharmacologic, endoscopic, or surgical means. The choice depends on the patient's comorbidities and therefore their candidacy for operative intervention.

In addition to reviewing the pathogenesis and diagnostic workup of achalasia, the various treatment modalities and newest emerging therapies that are hoped to evolve the field and improve treatment efficacy will be discussed in depth.

\section{Esophageal structure and motor innervation}

The esophagus consists of four primary layers - the mucosa, submucosa, muscularis propria, and adventitia. ${ }^{7}$ The muscularis propria consists of both a circular and longitudinal muscle layer. It gradually transitions from predominantly striated, skeletal muscle in the upper esophagus to predominantly smooth muscle in the lower esophagus. The esophagus terminates around the area of the diaphragmatic hiatus where

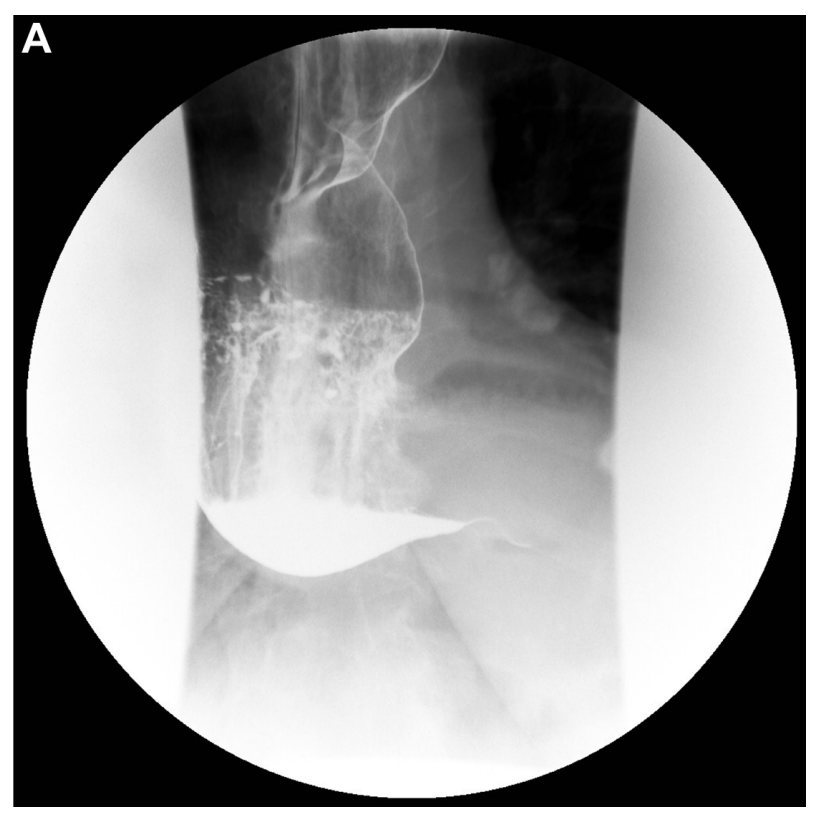

Figure I (Continued)
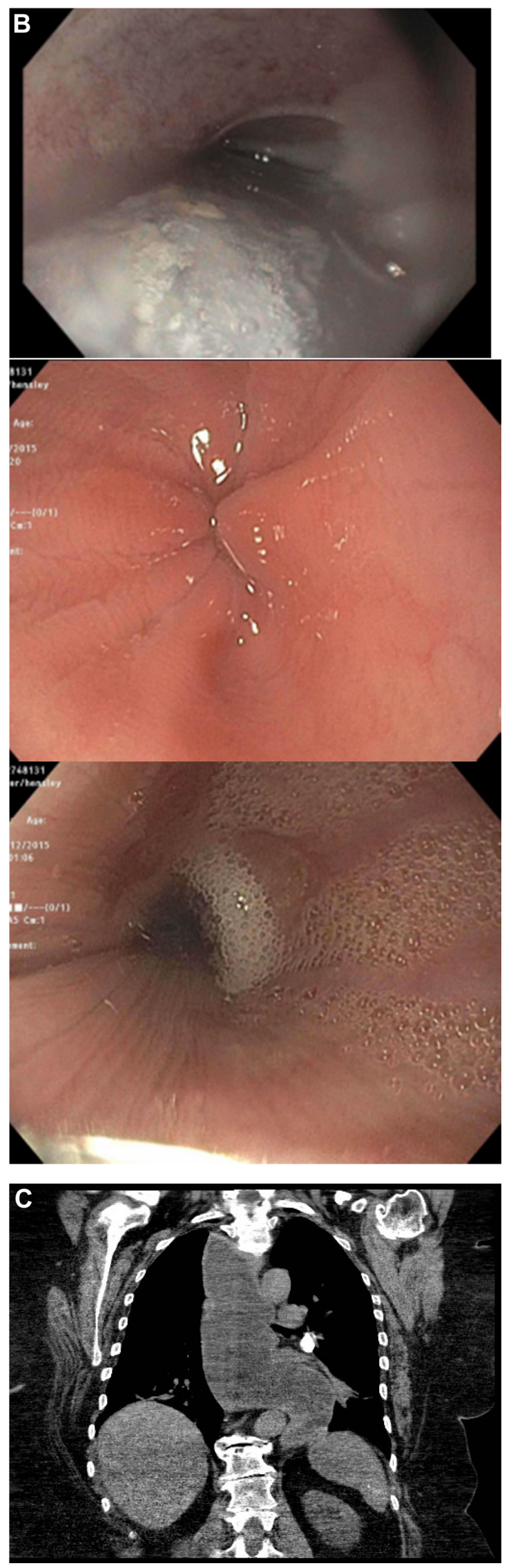

Figure I (Continued) 


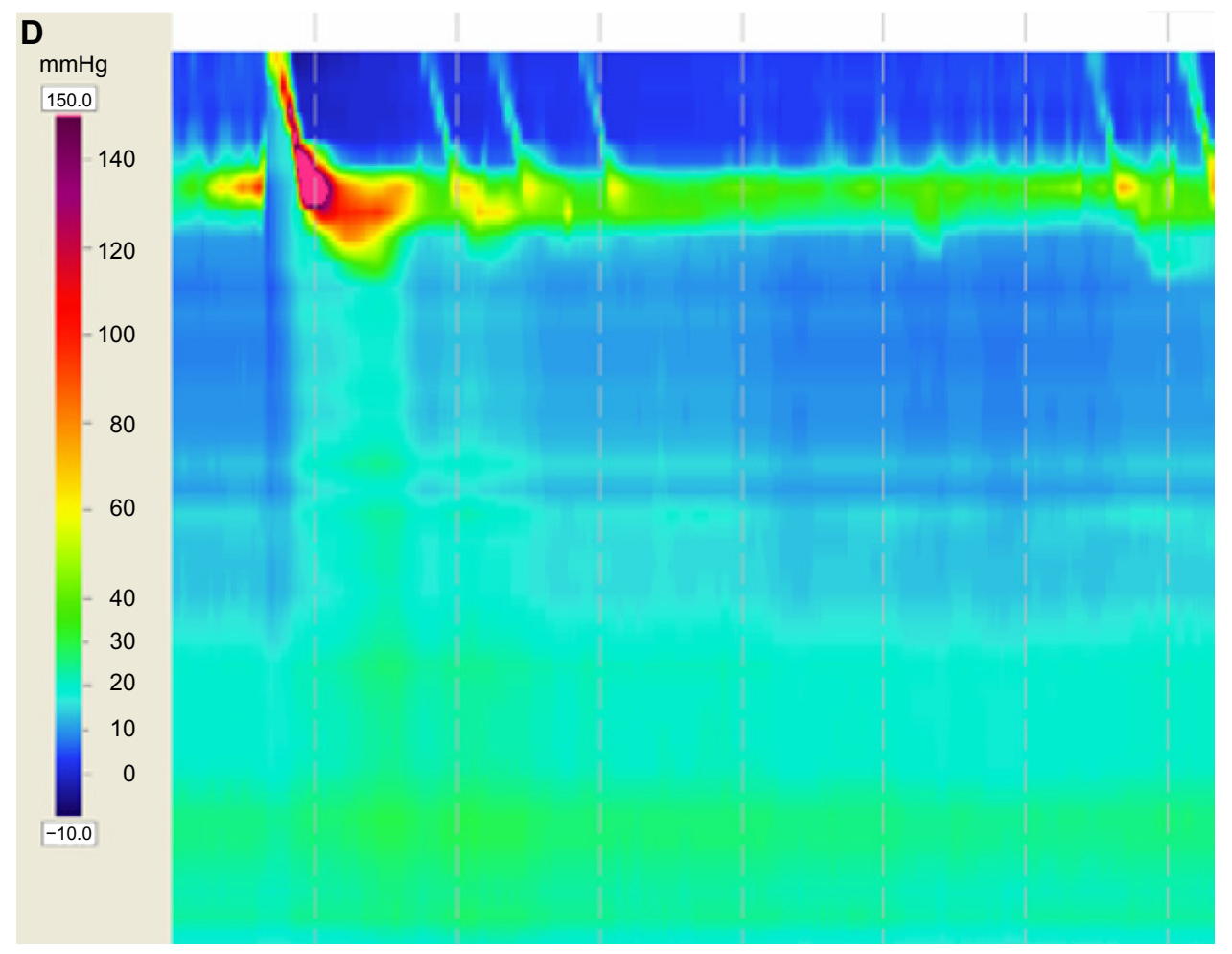

Figure I (A-D) Diagnostic tests for achalasia.

Notes: (A) Barium esophagram; (B) endoscopic appearance of achalasia; (C) chest computed tomography showing sigmoid esophagus; and (D) esophageal manometry showing type II achalasia.

there exists a $2-4 \mathrm{~cm}$ circular muscle layer, termed the lower esophageal sphincter. ${ }^{7}$

Esophageal motor innervation occurs through the vagus nerve via the intrinsic enteric nervous system; namely, the myenteric or Auerbach's plexus. The origin of neural innervation for the striated muscle of the proximal esophagus differs from that of the smooth muscle of the distal esophagus. The striated muscle of the proximal esophagus is predominantly innervated by somatic efferent fibers that have cell bodies originating from the nucleus ambiguous. They terminate on the motor end plate via cholinergic receptors. ${ }^{8,9}$ Alternatively, the smooth muscle of the distal esophagus is innervated by preganglionic neurons with cell bodies originating in the dorsal motor nucleus and terminating on the fibers of the myenteric plexus. ${ }^{10,11}$ The esophageal musculature (including the LES) is then innervated by postganglionic fibers. These consist of both excitatory neurons, which release acetylcholine resulting in esophageal and LES contraction, and inhibitory neurons, which release nitric oxide and vasoactive intestinal peptide resulting in relaxation. ${ }^{12,13}$ These neurons work together in a coordinated manner once a food or liquid bolus enters the esophagus to result in peristalsis that moves the bolus from the esophagus into the stomach.
In a normal functioning esophagus, inhibitory neurons are activated first to release nitric oxide, which relaxes the esophagus and allows for accommodation of the incoming food bolus. Following bolus front esophageal relaxation, there is a sequential activation of the excitatory neurons proximal to the bolus front to release acetylcholine, which then propels the food bolus forward.

Eventually, the peristaltic waves will propel the food bolus across the esophagogastric junction (EGJ) into the stomach. EGJ is a high-pressure area that is comprised of the LES, crural diaphragm, and proximal gastric cardia. ${ }^{7}$ Normal resting lower esophageal pressure is $10-30 \mathrm{mmHg}$, which functions to prevent reflux of gastric contents back into the esophagus. When the food bolus reaches the LES, it relaxes to allow passage into the stomach. This is achieved via activation of the inhibitory neurons resulting in the release of nitric oxide.

\section{Pathogenesis of achalasia}

The primary pathophysiologic disturbance resulting in achalasia is the selective loss of inhibitory innervation from the myenteric plexus of the distal esophagus and LES. ${ }^{14}$ The etiology for this process is unknown; however, genetics, 
infection, and autoimmune contributors have been discussed. The process may be an autoimmune phenomenon initiated by an indolent viral infection in a genetically predisposed host. ${ }^{15}$ Ultrastructural studies of esophageal tissue have found inflammatory infiltrate in the myenteric plexus of patients with achalasia compared to no inflammatory infiltrate in patients without achalasia. ${ }^{2,16}$ Additionally, a few case-control studies have suggested an association with HLA class II antigens and the development of idiopathic achalasia. ${ }^{17,18}$ Furthermore, Ruiz-de-Leon et al ${ }^{19}$ revealed that achalasia patients with these associated class II HLA antigens had a higher prevalence of circulating antimyenteric autoantibodies. This is strongly suggestive of an autoimmune component as the etiology. However, one should note that not all patients with achalasia have these associated HLA antigens. ${ }^{20}$

The consequence of the myenteric plexus inflammation is the degeneration of inhibitory postganglionic neurons of the esophagus and LES. ${ }^{21,22}$ This results in unopposed cholinergic stimulation leading to impaired relaxation of the LES and hypercontractility of the distal esophagus. ${ }^{7}$

\section{Diagnosis of achalasia}

The diagnosis of achalasia is typically suspected in a patient with dysphagia to both solids and liquids with associated regurgitation of undigested food. Complimentary tests include esophagogastroduodenoscopy and barium esophagram; however, definitive diagnosis should only be made following evaluation of esophageal motor function with manometric testing. ${ }^{1}$ The following are the diagnostic modalities often employed in achalasia.

\section{Esophageal manometry}

Esophageal manometry is the gold standard for the diagnosis of achalasia. It functions to assess esophageal pressures along the length of a flexible catheter inserted into the esophagus. The classic manometric finding of aperistalsis of the esophageal body and incomplete LES relaxation without evidence of mechanical obstruction is strongly supportive toward the diagnosis of achalasia. ${ }^{23}$ Other findings that include increased resting LES pressure and simultaneous nonpropagating contractions are also suggestive of the diagnosis, however, these are not required. ${ }^{24}$

Manometry, as a diagnostic tool, has evolved significantly over the past decade from conventional catheters with pressure sensors spaced 3-5 cm apart utilizing solid-state technology or a water-perfused extrusion catheter to high resolution manometry where pressure sensors are placed $1 \mathrm{~cm}$ apart with either water-perfused extrusion or solid-state technologies. ${ }^{1}$
High resolution manometry can display pressure data as esophageal topography plots (Figure 1D). Esophageal pressure topography gives the clinician the advantage of differentiating achalasia into three distinct subtypes that have important therapeutic outcome implications. ${ }^{23}$ Subtype II has the most favorable prognosis, whereas subtype III is the most difficult to treat. The prognosis of subtype I is somewhere in between. ${ }^{23,25,26}$

\section{Barium esophagram}

Esophageal dilation with a gradual taper down to the gastroesophageal junction giving a "bird's beak" appearance is the classic description of achalasia on barium esophagram (Figure 1A). Additional findings include aperistalsis and poor emptying of barium. ${ }^{1}$ Signs suggestive of late- or end-stage achalasia include tortuosity, angulation, and megaesophagus. ${ }^{1}$

An additional role for contrast radiography is the assessment of esophageal emptying following treatment of achalasia. Symptom relief often does not parallel esophageal emptying. Therefore, objective assessment of treatment response can be helpful in identifying patients at risk of failed treatment. This is accomplished by timed barium esophagram where the barium column height is measured at 1 and 5 minutes after upright ingestion of a large barium bolus. ${ }^{27}$ Subsequent studies have revealed the usefulness of timed barium esophagram for identifying patients at risk of failed treatment. ${ }^{28,29}$ Computed tomography can also be used to support an underlying diagnosis of achalasia and show the extent of disease, especially in those with sigmoid esophagus (Figure 1C); however, it is less sensitive and not commonly employed.

\section{Endoscopy}

Most patients presenting with dysphagia require esophagogastroduodenoscopy primarily to rule out a mechanical obstruction due to cancer that can mimic achalasia both clinically and manometrically. This is termed "pseudoachalasia." $30-32$ Similar to achalasia, mechanical obstruction can manometrically result in impaired LES relaxation and aperistalsis or spastic contractions of the esophageal body. ${ }^{33}$

Endoscopic findings of achalasia range from a grossly normal appearance to a tortuous, dilated sigmoid esophagus with retained food and saliva (Figure 1B). ${ }^{1}$ Oftentimes, the gastroesophageal junction will have a puckered appearance. Intubation of the stomach may give mild resistance; however, a strong resistance should raise suspicion of pseudoachalasia. $^{1}$ 
Of note, patients with achalasia can develop candidiasis secondary to esophageal stasis. Endoscopic evidence of candidiasis in the setting of immunocompetence suggests an esophageal motility disorder. ${ }^{7}$

\section{Clinical management of achalasia}

At the moment, there are no therapies that will reverse the loss of the inhibitory interneurons of the myenteric plexus and restore normal esophageal motility. Current treatment options aim to reduce the hypertonicity of the LES to improve esophageal emptying by gravity. This is attempted via oral pharmacologic therapy, endoscopic therapy, or surgery. The choice of treatment is dependent on patient age, comorbidities, severity, patient preference, and locally available expertise. ${ }^{34}$ Currently, pneumatic dilation (PD) and surgical myotomy are considered the most effective therapies. Other options are employed in those who are not candidates for these more effective therapies. ${ }^{1}$ Regardless of the intervention, LES hypertonicity returns over time requiring repeat intervention. The decision on treatment options is based on several factors, including operative candidacy and durability (Table 1).

\section{Oral pharmacologic therapy}

Oral pharmacologic therapies are considered the least effective treatment option for achalasia. ${ }^{35}$ The clinical response to these agents is short lived and their side effect profile is

Table I Pros and cons of conventional treatments for achalasia

\begin{tabular}{|c|c|c|}
\hline Therapy & Pros & Cons \\
\hline Medical therapy & $\begin{array}{l}\text { - On demand } \\
\text { - Minimal risk } \\
\text { - Option for nonoperative } \\
\text { candidates }\end{array}$ & $\begin{array}{l}\text { - Least effective } \\
\text { treatment option }{ }^{35} \\
\text { - Not durable }\end{array}$ \\
\hline $\begin{array}{l}\text { Botulinum toxin } \\
\text { injection }\end{array}$ & $\begin{array}{l}\text { - Good option for } \\
\text { nonoperative candidates } \\
\text { - Short procedure time }\end{array}$ & $\begin{array}{l}\text { - Durability of } \\
6-12 \text { months } s^{44}\end{array}$ \\
\hline Pneumatic dilation & $\begin{array}{l}\text { - Most effective nonsurgical } \\
\text { option }{ }^{1,5} \\
\text { - Durability } 2-5 \text { years }^{96} \\
\text { - Procedure time }<30 \text { minutes } \\
\text { - Short recovery time }\end{array}$ & $\begin{array}{l}\text { - Perforation } \\
(1 \%-5 \%)\end{array}$ \\
\hline Surgical myotomy & $\begin{array}{l}\text { - Durability } 5-7 \text { years }^{96} \\
\text { - Procedure time } \sim 90 \text { minutes }\end{array}$ & $\begin{array}{l}\text { - General anesthesia } \\
\text { required } \\
\text { - Hospital stay of } \\
\text { I-2 days }\end{array}$ \\
\hline Esophagectomy & $\begin{array}{l}\text { - For end-stage disease } \\
\text { - Treatment-resistant } \\
\text { achalasia }\end{array}$ & $\begin{array}{l}\text { - High morbidity and } \\
\text { mortality } \\
\text { - Anastomotic } \\
\text { strictures } \\
\text { - Chronic vomiting } \\
\text { in some }\end{array}$ \\
\hline
\end{tabular}

unfavorable. Additionally, they do not provide complete alleviation of symptoms and therefore they are usually reserved for patients who are poor candidates for more effective therapies ( $\mathrm{PD}$, surgical myotomy) or in those who have failed botulinum toxin injections (BTIs). ${ }^{1}$ The aim of these medications is to induce smooth muscle relaxation of the LES thereby facilitating passage of esophageal contents into the stomach. The two most commonly employed medications are calcium channel blockers and long-acting nitrates. Sildenafil, a phosphodiesterase-5-inhibitor, is another option. ${ }^{36}$ Other less commonly used medications include anticholinergics, $\beta$-adrenergic agonists, and theophylline.

\section{Endoscopic pharmacologic therapy}

Botulinum toxin, a potent inhibitor of acetylcholine release from the presynaptic terminals by cleaving the SNAP-25 protein, is a useful treatment strategy for patients who are unable to tolerate more invasive therapies, such as PD or surgical myotomy. The objective of this therapy is to block unopposed cholinergic stimulation caused by the selective loss of inhibitory interneurons that release neurotransmitters to relax the LES. ${ }^{37}$

The technique involves injecting up to 100 units of toxin with a sclero-needle just proximal to the squamo-columnar junction evenly distributed over four quadrants. Doses greater than 100 units are shown to be no more effective. ${ }^{38}$ Complications related to the procedure are rare and typically involve chest pain seen in $16 \%-25 \%$. Rare, more serious, complications include mediastinitis and an allergic reaction to an egg-based protein. Additionally, repeated BTIs can lead to subsequent submucosal fibrosis making future surgical myotomy difficult. ${ }^{39-41}$ Therefore, BTI should be reserved for patients in whom PD and surgical myotomy are precluded due to operative risk factors. ${ }^{42}$

The response rate in the first month of treatment is high at $80 \%-90 \%$; however, the therapeutic effect wanes rapidly over time such that $\sim 50 \%$ of patients are symptomatic at 1 year. ${ }^{38,43,44}$ Thus, repeat treatments every $6-12$ months are often required. Factors predictive of a favorable and prolonged response to BTI are older age ( $>40$ years old), a type II manometric pattern, and a decreased basal LES pressure following treatment. ${ }^{44}$

\section{Pneumatic dilation}

$\mathrm{PD}$, a procedure employing air pressures to disrupt or fracture the LES circular muscle fibers, is the most effective nonsurgical option in the treatment of achalasia. ${ }^{1,5}$ Currently, the most widely used balloon dilator is the Rigiflex, a nonradiopaque 
graded size polyethylene balloon. Another less commonly employed and essentially abandoned balloon dilator is the Witzel dilator that comes in only one size $(4.0 \mathrm{~cm}$ balloon). This has fallen out of favor over the past years.

With Rigiflex dilators, the procedure can be performed under radiologic guidance (fluoroscopy); although balloon positioning under direct endoscopic guidance can also be employed. ${ }^{45,46}$ The dilators are available in three diameters $(3.0,3.5$, and $4.0 \mathrm{~cm})$. There are two different strategies for performing PD that include a single dilation approach and a graded dilation approach. When employing the graded approach, relief of symptoms is possible in $50 \%-93 \%$ of patients. ${ }^{5,35,47,48}$ One cross-sectional study demonstrated that symptomatic response to a single PD was $62 \%$ at 6 months and $28 \%$ at 2 years compared to $90 \%$ at 6 months and $44 \%$ at 6 years in the graded PD cohort. ${ }^{47}$

Graded PD is performed by an initial dilation at $3.0 \mathrm{~cm}$, then $3.5 \mathrm{~cm}$, and finishing at $4.0 \mathrm{~cm}$ with 4-6 weeks in between dilations. Reassessment of symptoms and LES pressure can be performed between each session to determine the necessity of subsequent treatments. Additionally, the rate of perforation may be lower with the graded dilation approach. ${ }^{1}$

It is estimated that a third of patients treated with PD will experience symptom relapse within $4-6$ years. ${ }^{1}$ Predictive factors of a poor clinical response to treatment include age $<40$ years, ${ }^{49-51}$ male sex,${ }^{52}$ LES pressure after dilation greater than $10-15 \mathrm{mmHg},{ }^{53}$ and continued symptoms after one or two treatments. ${ }^{52-55}$ Additionally, males younger than 45 years of age may not be as responsive to the serial approach. This is possibly due to thicker LES musculature. In these patients, it is recommended to either start with PD at $3.5 \mathrm{~cm}$ or proceed straight to surgical myotomy as the initial step in management. ${ }^{1}$ Of note, patients with a type II high resolution manometry pattern have been shown to have better outcomes. ${ }^{25}$

All patients being considered for PD must also be appropriate surgical candidates as esophageal perforation is a known complication of this procedure. The rate of perforation is $\sim 1.9 \%$ but is shown to range from $0 \%$ to $5 \% .47,56$ Although there are no factors predictive of perforation, it is believed to most commonly occur during the initial dilation and is thought to be related to improper balloon positioning. ${ }^{57}$ Small, asymptomatic perforations can be managed conservatively with parenteral nutrition, antibiotics, and stent placement. ${ }^{58}$ However, for large perforations with mediastinal contamination, surgical repair through thoracostomy is required. ${ }^{1}$ An additional complication includes gastroesophageal reflux disease (GERD), which is seen in $15 \%-35 \%$ of patients following PD. Therefore, starting a proton pump inhibitor following PD in those with preexisting GERD is recommended. ${ }^{59}$

\section{Surgical myotomy}

Surgical myotomy, a technique involving the division of the circular muscle fibers of the LES, was initially performed via an open thoracotomy and laparotomy approach. Studies at the time revealed good response with $60 \%-94 \%$ of patients achieving symptomatic improvement when followed over 1-36 years. ${ }^{35}$ However, over time, this approach was replaced with more minimally invasive techniques; first with thoracoscopy which was then replaced with laparoscopic myotomy because of improved morbidity and faster recovery time. ${ }^{60}$ Additionally, these minimally invasive techniques can be performed with similar efficacy to the open approach; $94 \%$ versus $84 \%$, respectively. ${ }^{35}$

There are no randomized control trials comparing the different approaches of surgical myotomy. All published data in this area are prospective or retrospective cohort and case-control studies. A systematic review analyzing surgical techniques in 4,871 patients reported patient symptom improvement after all surgical myotomies. This included $84.5 \%$ of those who underwent the open transabdominal approach, $83.3 \%$ of those with the open transthoracic approach, $77.6 \%$ of those with the thoracoscopic approach, and $89.3 \%$ of those who had a laparoscopic myotomy. ${ }^{48}$ A subset of the analysis comparing studies with laparoscopic Heller myotomy (LHM) $(3,086)$ and the thoracoscopic approach (211) showed better symptomatic improvement with the laparoscopic approach compared to the thoracoscopic approach $(89.3 \%$ vs $77.6 \%, P=0.048) .^{48}$

GERD is a known and frequent complication following surgical myotomy thereby making intraoperative fundoplication a consideration to remedy it. The incidence of postoperative reflux symptoms is reported to be lower for the laparoscopic than for the thoracoscopic approach $(28.3 \%$ vs $14.9 \%, P=0.03)$ and open transthoracic approach $(24.6 \%$ vs $14.9 \%, P=0.04) .{ }^{48}$ Reflux may be less if fundoplication is added to myotomy ( $41.5 \%$ without fundoplication vs $14.5 \%$ with fundoplication, $P=001) .^{48} \mathrm{~A}$ randomized controlled trial comparing myotomy with or without fundoplication reported that performing intraoperative fundoplication was associated with a lower incidence of postoperative reflux. ${ }^{61}$ Therefore, in the guidelines published by the Society of American Gastrointestinal and Endoscopic Surgeons, it is recommended to perform fundoplication in patients who undergo myotomy. ${ }^{62}$ Additionally, the rate of postoperative 
dysphagia is shown to be independent of whether or not a fundoplication was performed after myotomy. ${ }^{48}$ Of note, Rawlings et $\mathrm{al}^{63}$ demonstrated in a randomized control trial comparing anterior Dor with posterior Toupet fundoplications that both provide similar outcomes in terms of postoperative reflux following LHM.

Of note, robotic surgery is an emerging minimally invasive alternative to LHM. It is a computer-assisted device under the remote control of a surgeon. It has the benefit of providing a magnified surgical field that allows for more precise movements thereby reducing complications. ${ }^{64}$

\section{Esophagectomy}

"End-stage" achalasia, characterized by a dilated and tortuous esophagus (megaesophagus or sigmoid esophagus), is often unresponsive to conventional treatments for achalasia. Although PD is ineffective, surgical myotomy should still be considered the initial treatment before consideration of the more morbid esophagectomy. Two recent studies involving patients with megaesophagus revealed that surgical myotomy resulted in improvement of symptoms ranging from $72 \%$ to $92 \%{ }^{65,66}$ When symptoms are unresponsive to myotomy, esophagectomy should be the next step for consideration. ${ }^{67}$ Observational studies do show symptomatic response of up to $80 \%$ with esophagectomy; however, its association with a greater morbidity and mortality make it a last resort treatment modality. ${ }^{68}$

\section{Advances in treatment for achalasia Peroral endoscopic myotomy}

Peroral endoscopic myotomy (POEM), a minimally invasive endoscopic technique, is one of the most recent advances in the treatment of achalasia (Table 2). It was first described in a case series published in 1980 by Ortega et al $^{69}$ where two
$1 \mathrm{~cm}$ long myotomies were performed through the mucosa at a depth of $3 \mathrm{~mm}$. However, this was not further studied until 2007 when Pasricha et al ${ }^{70}$ demonstrated endoscopic myotomy in a porcine model. Then, in 2010, Inoue et $\mathrm{al}^{71}$ published a prospective trial of 17 patients undergoing endoscopic myotomy that revealed significant reduction in the index of dysphagia symptoms ( 10 to $1.3, P=0.0003$ ) as well as resting LES pressure ( 52.4 to $19.9 \mathrm{mmHg}, P=0.0001$ ). No serious complications were reported. It was at this point where endoscopic myotomy became adopted into clinical practice. ${ }^{72}$ In 2012, von Renteln et al ${ }^{73}$ published another prospective trial. It included 16 patients and illustrated symptomatic response in $94 \%$ after 3 months. Furthermore, resting LES pressure was reduced from 27.3 to $11.8 \mathrm{mmHg}(P<0.001)$. In 2014, Bhayani et al ${ }^{74}$ conducted a prospective observational study that compared 64 patients treated by LHM and 37 by POEM. It showed that mean operative time and length of stay were significantly higher in the LHM cohort but complication rates were similar. Patient symptoms, manometry, and postoperative esophageal acid exposure revealed similar outcomes among the two groups.

The preparation for POEM begins with a liquid diet 1-5 days prior to the procedure to minimize residual food in the esophagus. ${ }^{75}$ The first step in the procedure involves injection of $10 \mathrm{~mL}$ of saline solution with contrast (methylene blue or indigo carmine) to the central esophagus $10-16 \mathrm{~cm}$ proximal to the squamo-columnar junction. ${ }^{72}$ The purpose of this is to expand the submucosa so it is easily accessed for dissection and tunnel formation. This allows safer access to the circular muscle layer. Following this, a $2 \mathrm{~cm}$ incision is made to gain access into the submucosal space. Then, a submucosal tunnel is dissected through the EGJ and 2-3 cm into the gastric cardia. ${ }^{76}$ Once access is made to the circular muscle layer of

Table 2 Studies evaluating the efficacy of perioral endoscopic myotomy (POEM)

\begin{tabular}{|c|c|c|c|c|c|}
\hline Author & Year & Study design & Inclusion criteria & Population & Outcome \\
\hline $\begin{array}{l}\text { Inoue } \\
\text { et } \mathrm{al}^{71}\end{array}$ & 2010 & $\begin{array}{l}\text { Prospective } \\
\text { observational }\end{array}$ & $\begin{array}{l}\text { Adults }>18 \text { years old } \\
\text { Proven achalasia by } \\
\text { manometry }\end{array}$ & I7 patients treated by POEM & $\begin{array}{l}\text { - Significant reduction in the index of dysphagia } \\
\text { symptoms } \\
\text { - Significant reduction in resting LES pressure }\end{array}$ \\
\hline $\begin{array}{l}\text { von Renteln } \\
\text { et } \mathrm{al}^{73}\end{array}$ & 2012 & $\begin{array}{l}\text { Prospective } \\
\text { observational }\end{array}$ & $\begin{array}{l}\text { Adults }>18 \text { years old } \\
\text { Symptomatic achalasia } \\
\text { Medical indication for } \\
\text { LHM or PD }\end{array}$ & 16 patients treated by POEM & $\begin{array}{l}\text { - Postprocedure Eckardt symptom score } \leq 3 \\
\text { in } 94 \% \\
\text { - Significant reduction in resting LES pressure }\end{array}$ \\
\hline $\begin{array}{l}\text { Bhayani } \\
\text { et } \mathrm{al}^{74}\end{array}$ & 2014 & $\begin{array}{l}\text { Prospective } \\
\text { observational } \\
\text { LHM vs POEM }\end{array}$ & $\begin{array}{l}\text { Patients with achalasia } \\
\text { LHM or POEM from } \\
2007 \text { to } 2012 \text { at a single } \\
\text { institution }\end{array}$ & $\begin{array}{l}\text { I0I patients } \\
\text { LHM ( } n=64 ; 42 \% \text { Toupet and } \\
58 \% \text { Dor fundoplications) or } \\
\text { POEM ( } n=37)\end{array}$ & $\begin{array}{l}\text { - I-Month Eckardt scores significantly better } \\
\text { for POEMs } \\
\text { - 6-Month Eckardt scores similar improvements } \\
\text { (I.7 vs I.2, P=0.I) } \\
\text { - Mean hospitalization significantly higher for LHMs }\end{array}$ \\
\hline
\end{tabular}

Abbreviations: LES, lower esophageal sphincter; PD, pneumatic dilation; LHM, laparoscopic Heller myotomy. 
the LES, the myotomy is usually extended to $6 \mathrm{~cm}$ into the esophagus and $2 \mathrm{~cm}$ below the EGJ. ${ }^{20}$

Serious adverse events are rare with POEM. They occur at a rate of $<0.1 \%$ with the most common serious event being perforation. ${ }^{77}$ Another, albeit less serious, complication following POEM is GERD. In carefully selected patients, some studies have shown short-term postoperative clinical symptoms of GERD following POEM is $10.9 \%$, comparable to that of LHM. $^{78}$

\section{Self-expanding metal stents}

The use of esophageal self-expanding metal stent (SEMS) has long been beneficial in the treatment of esophageal malignancies, esophageal perforations, and anastomotic leaks. There have been a few studies published in the recent past that have described the utility of SEMS in benign esophageal disease, particularly achalasia (Table 3 ). ${ }^{79,80}$

In 2009, Zhao et al ${ }^{81}$ published a prospective observational study that concluded temporary SEMS to be a safe and effective modality in the management of achalasia with very good long-term symptomatic response rates. It involved 75 patients with achalasia who were treated with a temporary $30 \mathrm{~mm}$ diameter SEMS. They were placed under fluoroscopic guidance and removed via gastroscopy 4-5 days later. Follow-up was arranged at 6 months, 1 year, 3-5 years, 5-8 years, 8-10 years, and $>10$ years. Clinical response was $100 \%$ at 1 month and $83.3 \%$ at follow-up past 10 years. Complications were few but included migration (5.3\%), chest pain (38.7\%), and reflux $(20 \%)$. There were no perforations or 30 -day mortality.

Cheng et al, $^{79}$ in 2010 , published another prospective observational study comparing the efficacy of 20,25 , and
$30 \mathrm{~mm}$ diameter temporary SEMS. It involved a total of 90 patients with follow-up arranged at 6 months and 1, 3-5, $5-8,8-10$, and $>10$ years. The study found that patients who received the $30 \mathrm{~mm}$ diameter SEMS had the best clinical response and lowest incidence of stent migration. It found that the clinical symptomatic remission rate with $30 \mathrm{~mm}$ SEMS at $>10$ years was $83.3 \%$. This is comparable to the long-term clinical response of those who underwent LHM. In 2010, Li et al, ${ }^{82}$ along with the same authors above at the same institution, published a prospective study comparing $30 \mathrm{~mm}$ SEMS with PD. It found that the clinical remission rate in those treated with PD was $0 \%$ at 10 years compared with $83.3 \%$ at 10 years in those treated with a $30 \mathrm{~mm}$ SEMS.

Although the results of the earlier studies are promising, they were published at a single institution and therefore their generalizability is questionable. Further investigation with randomized controlled trials will still be needed before they become accepted into clinical practice.

\section{Endoscopic sclerotherapy}

Two recent studies have been published describing the use of a sclerosing agent, ethanolamine oleate, in the treatment of achalasia (Table 4). ${ }^{83,84}$ The theory prompting its investigation was based on its necrotizing effect on the applied muscle.

In 2013, Moreto et $\mathrm{a}^{83}$ published a study involving 103 patients who received endoscopic sclerotherapy every 2 weeks until dysphagia resolved. It reported a symptom remission rate of $90 \%$ at 50-month follow-up. In 2014, Niknam et $\mathrm{al}^{84}$ performed a study involving 31 patients who received three treatments of ethanolamine oleate injections

Table 3 Studies evaluating the efficacy of self-expanding metal stent (SEMS)

\begin{tabular}{|c|c|c|c|c|c|}
\hline Author & Year & Study design & Inclusion criteria & Population & Outcome \\
\hline Zhao et $\mathrm{al}^{8 \mathrm{I}}$ & 2009 & $\begin{array}{l}\text { Prospective } \\
\text { observational }\end{array}$ & $\begin{array}{l}\text { Documented primary achalasia } \\
\text { Recurrent dysphagia following } \\
\text { pneumatic balloon dilation } \\
\text { Life expectancy }>6 \text { months }\end{array}$ & $\begin{array}{l}75 \text { patients who had a } \\
30 \mathrm{~mm} \text { SEMS placed }\end{array}$ & $\begin{array}{l}\text { - Symptom remission rate was } 100 \% \text { at } \\
\text { - Significant reduction in } 6 \text {-month mean } \\
\text { dysphagia score }\end{array}$ \\
\hline Cheng et $\mathrm{al}^{79}$ & 2010 & $\begin{array}{l}\text { Prospective } \\
\text { observational }\end{array}$ & $\begin{array}{l}\text { Documented primary achalasia } \\
\text { Recurrent dysphagia following } \\
\text { pneumatic balloon dilation } \\
\text { Life expectancy }>6 \text { months }\end{array}$ & $\begin{array}{l}90 \text { patients treated with } \\
20 \mathrm{~mm}(\mathrm{n}=30), 25 \mathrm{~mm} \\
(\mathrm{n}=30) \text {, or } 30 \mathrm{~mm}(\mathrm{n}=30) \\
\text { SEMS }\end{array}$ & $\begin{array}{l}\text { - } 30 \mathrm{~mm} \text { diameter SEMS group had } \\
\text { the best clinical response and lowest } \\
\text { incidence of stent migration } \\
\text { - Clinical symptomatic remission rate } \\
\text { with } 30 \mathrm{~mm} \text { SEMS at }>10 \text { years was } \\
83.3 \% \text {, comparable to the long-term } \\
\text { clinical response of those who } \\
\text { underwent LHM }\end{array}$ \\
\hline Li et $a^{82}$ & 2010 & $\begin{array}{l}\text { Prospective } \\
\text { observational trial } \\
\text { comparing } 30 \mathrm{~mm} \\
\text { SEMS with PD }\end{array}$ & $\begin{array}{l}\text { Documented primary achalasia } \\
\text { Recurrent dysphagia following } \\
\text { pneumatic balloon dilation } \\
\text { Life expectancy }>6 \text { months }\end{array}$ & $\begin{array}{l}\text { I } 55 \text { patients allocated to } \\
\text { PD }(n=80) \text { or } 30 \mathrm{~mm} \\
\text { diameter SEMS }(n=75)\end{array}$ & $\begin{array}{l}\text { - Clinical remission rate in those } \\
\text { treated with PD was } 0 \% \text { at } 10 \text { years } \\
\text { compared with } 83.3 \% \text { at } 10 \text { years in } \\
\text { those treated with a } 30 \mathrm{~mm} \text { SEMS }\end{array}$ \\
\hline
\end{tabular}

Abbreviations: PD, pneumatic dilation; LHM, laparoscopic Heller myotomy. 
Table 4 Studies evaluating the efficacy of endoscopic sclerotherapy

\begin{tabular}{|c|c|c|c|c|c|}
\hline Author & Year & Study design & Inclusion criteria & Population & Outcome \\
\hline Moreto et $\mathrm{al}^{83}$ & 2013 & $\begin{array}{l}\text { Prospective } \\
\text { observational }\end{array}$ & $\begin{array}{l}\text { Diagnosis of achalasia by } \\
\text { manometry }\end{array}$ & $\begin{array}{l}\text { I03 patients treated with } \\
\text { ethanolamine oleate (EO) } \\
\text { or polidocanol }\end{array}$ & $\begin{array}{l}\text { Symptom remission rate of } 90 \% \\
\text { at } 50 \text { months with } \mathrm{EO} \text {, but only } \\
65 \% \text { with polidocanol }\end{array}$ \\
\hline Niknam et $\mathrm{al}^{84}$ & 2014 & $\begin{array}{l}\text { Prospective } \\
\text { observational }\end{array}$ & $\begin{array}{l}\text { Poor candidates for PD; } \\
\text { resistance to PD; high operative } \\
\text { risk or unwillingness to undergo } \\
\text { surgery; poor or no response } \\
\text { to HM }\end{array}$ & $\begin{array}{l}31 \text { patients who received } \\
\text { three treatments of EO } \\
\text { injections at } 2 \text {-week intervals }\end{array}$ & $\begin{array}{l}\text { - Mean achalasia symptom score } \\
\text { and mean volume of retained } \\
\text { barium in TBE at } 12 \text { months were } \\
\text { significantly reduced compared } \\
\text { with preinjection scores }\end{array}$ \\
\hline
\end{tabular}

Abbreviations: PD, pneumatic dilation; TBE, timed barium esophagram; HM, Heller myotomy; EO, ethanolamine oleate.

at 2-week intervals. They found that the mean symptom score at 12 months was significantly reduced compared with preinjection scores. It is important to note that, if the use of this procedure is entertained, it should be considered only in those with refractory achalasia who are not candidates for PD or surgical myotomy because there is a thought that the LES fibrosis that ensues might make invasive therapies more difficult. ${ }^{85}$

\section{Comparison of therapeutic modalities PD versus $B T I$}

Multiple randomized controlled trials have been conducted comparing the efficacy of PD and BTI. In 2006, Leyden et $\mathrm{al}^{86}$ published a systematic review of seven randomized controlled trials totaling 178 patients. It found similar outcomes at a short-term follow-up of 4 weeks from the initial procedure. However, three studies within the review recorded a 12-month follow-up that discovered a significant difference in response. It found 55 of 75 (73.3\%) PD subjects were in symptomatic remission compared to 27 of $72(37.5 \%)$ BTI subjects (relative risk 1.88, $P=0.0002$ ). Similar results were elucidated by a systematic review published by Wang et al ${ }^{87}$ in 2009. Therefore, current evidence supports that PD is more effective than BTI in achieving long-term symptomatic response.

\section{PD versus $B$ TI-PD}

In 2006, Mikaeli et al ${ }^{88}$ performed a randomized controlled trial comparing PD alone versus BTI before PD. At 1-year follow-up, it found remission rates were slighter higher in the BTI-PD group (77\%) compared with the group that received PD alone (62\%). In 2009, Zhu et a ${ }^{89}$ published a randomized controlled trial that compared $\mathrm{PD}$ alone versus BTI alone versus PD with BTI 15 days later. All subjects were followed for 2 years. At 2 years, clinical remission was achieved in $13.7 \%$ treated with BTI alone, $35.7 \%$ in those treated with PD alone, and $56.6 \%$ in those who received combination therapy. However, despite the earlier evidence, given the concern for fibrosis induced by BT, in clinical practice $\mathrm{BT}$ is not combined with pre- or post-PD in those who are candidates for definitive therapy with either PD alone or surgical myotomy.

\section{PD versus $L H M$}

In their systematic review, Campos et $\mathrm{a}^{48}$ compared the efficacy of LHM and PD. It totaled 3,086 patients treated with LHM and 1,065 treated with PD. The study demonstrated significantly improved symptomatic relief in those treated with LHM compared to those treated with PD at 12 months (89.3\% vs $68.2 \%)$ and past 36 months ( $89.3 \%$ vs $56.3 \%)$.

More recently, in 2011, Boeckxstaens ${ }^{90}$ conducted a randomized controlled trial comparing LHM to PD. In all, 95 patients were randomized to receive $\mathrm{PD}$ and 106 patients were randomized to undergo LHM with a mean follow-up time of 43 months. The primary outcome was therapeutic success (as defined by a drop in Eckardt score to $<3$ ). It found a comparable success rate for both treatments at 1 year ( $90 \%$ in PD vs $93 \%$ in LHM) and at 2 years ( $86 \%$ in PD vs $90 \%$ in LHM).

A recent meta-analysis published by Weber et $\mathrm{al}^{91}$ in 2012 found that LHM has greater durability than PD. It included 36 studies with 3,211 patients in the PD group and 1,526 patients in the LHM group. In those treated with PD, it found the mean 5 -year remission rate to be $61.9 \%$ and mean 10 -year remission rate to be $47.9 \%$. In those treated with LHM, it found the mean 5- and 10-year remission rates were $76.1 \%$ and $79.6 \%$, respectively. ${ }^{91}$ It also found a perforation rate for those treated with LHM to be double that of those treated with PD ( $4.8 \%$ vs $2.4 \% ; P<0.05)$.

Therefore, based on the available evidence, success rates for PD and LHM are believed to be comparable although LHM may be associated with greater long-term durability, especially in younger males. 


\section{Treatment algorithm}

A generally agreed upon stepwise treatment algorithm for achalasia is illustrated in Figure 2. Many factors are considered in the selection of the appropriate therapy. They include age, sex, comorbidities and surgical risk, type of achalasia, and available expertise. ${ }^{92}$

In general, patients with achalasia who are deemed good surgical candidates should be referred for consideration of PD or LHM. Although evidence has shown both therapies to be equally effective in the short term, LHM is the most durable form of treatment for long-term symptom remission, especially in younger male patients. ${ }^{1,91}$

One recent study determined outcomes in the treatment of achalasia based on manometric subtype. For PD, it reported response rates of $96 \%$ in patients with type II achalasia, 56\% for type I, and 29\% for type III. ${ }^{93}$ Therefore, PD seems to be most effective in the treatment of type II achalasia. Although PD is shown to induce longterm symptomatic remission, multiple sessions are often required due to symptom recurrence. PD is considered a failed treatment when there is lack of symptom improvement after 2-3 sessions or following the use of the largest diameter balloon. In these situations, referral to surgery for consideration of surgical myotomy is most appropriate. ${ }^{72}$ Furthermore, it is appropriate to consider PD in patients who have failed initial treatment with surgical myotomy and who have recurrence of symptoms.

Surgical myotomy is shown to be an effective therapy for inducing long-term symptomatic remission.${ }^{91}$ In patients who are good operative candidates, it is recommended in adolescents and young adults (especially male), ${ }^{94}$ patients with achalasia type III, ${ }^{93}$ patients with pulmonary symptoms, and those who have not responded to two to three sessions of PD or following the use the largest diameter balloon. ${ }^{72}$
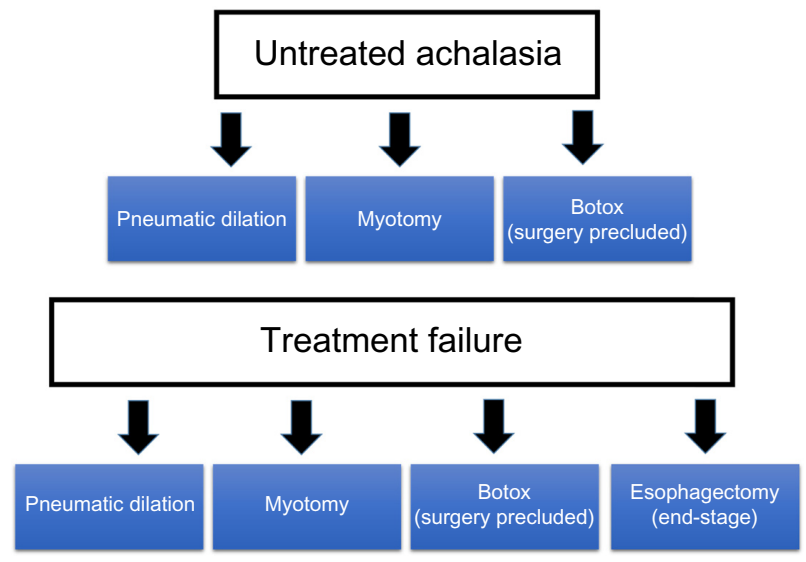

Figure 2 Treatment algorithm for achalasia.
BTI is considered first-line therapy in patients with advanced age, short life expectancy, and significant comorbidities who are high risk of PD and surgical myotomy. ${ }^{42}$ Oral pharmacologic therapies with nitrates, calcium channel blockers, and phosphodiesterase-5-inhibitors (sildenafil) are generally recommended for patients who cannot undergo more definitive treatment with PD/LHM or in whom BTI has failed. They theoretically function to reduce pressure at the LES but the efficacy is very poor. In general, BTI and oral pharmacologic therapies should only be considered in high-risk patients or as a stepping stone to more definitive therapies. $^{95}$

POEM is an emerging therapy for patients with achalasia but at this time there is no general consensus as to where it will fall within the achalasia treatment algorithm. Randomized controlled trials will have to be undertaken before it becomes widely accepted into clinical practice. However, the preliminary reports are promising for its role as a potential initial therapy in select group of patients.

\section{Disclosure}

The authors report no conflicts of interest in this work.

\section{References}

1. Vaezi MF, Pandolfino JE, Vela MF. ACG clinical guideline: diagnosis and management of achalasia. Am J Gastroenterol. 2013;108(8): 1238-1249; quiz 1250.

2. Clark SB, Rice TW, Tubbs RR, Richter JE, Goldblum JR. The nature of the myenteric infiltrate in achalasia: an immunohistochemical analysis. Am J Surg Pathol. 2000;24(8):1153-1158.

3. Richter JE. The diagnosis and misdiagnosis of achalasia: it does not have to be so difficult. Clin Gastroenterol Hepatol. 2011;9(12): 1010-1011.

4. Kessing BF, Bredenoord AJ, Smout AJ. Erroneous diagnosis of gastroesophageal reflux disease in achalasia. Clin Gastroenterol Hepatol. 2011;9(12):1020-1024.

5. Vaezi MF, Richter JE. Diagnosis and management of achalasia. American College of Gastroenterology Practice Parameter Committee. Am J Gastroenterol. 1999;94(12):3406-3412.

6. Francis DL, Katzka DA. Achalasia: update on the disease and its treatment. Gastroenterology. 2010;139(2):369-374.

7. Pandolfino JE, Gawron AJ. Achalasia: a systematic review. JAMA. 2015;313(18):1841-1852.

8. Bieger D, Hopkins DA. Viscerotopic representation of the upper alimentary tract in the medulla oblongata in the rat: the nucleus ambiguus. J Comp Neurol. 1987;262(4):546-562.

9. Toyama T, Yokoyama I, Nishi K. Effects of hexamethonium and other ganglionic blocking agents on electrical activity of the esophagus induced by vagal stimulation in the dog. Eur J Pharmacol. 1975; 31(1):63-71.

10. Collman PI, Tremblay L, Diamant NE. The central vagal efferent supply to the esophagus and lower esophageal sphincter of the cat. Gastroenterology. 1993;104(5):1430-1438.

11. Goyal RK, Rattan S. Nature of the vagal inhibitory innervation to the lower esophageal sphincter. J Clin Invest. 1975;55(5):1119-1126.

12. Goyal RK, Rattan S, Said SI. VIP as a possible neurotransmitter of non-cholinergic non-adrenergic inhibitory neurones. Nature. 1980;288(5789):378-380. 
13. Yamato S, Spechler SJ, Goyal RK. Role of nitric oxide in esophageal peristalsis in the opossum. Gastroenterology. 1992;103(1):197-204.

14. Goldblum JR, Whyte RI, Orringer MB, Appelman HD. Achalasia A morphologic study of 42 resected specimens. Am J Surg Pathol. 1994;18(4):327-337.

15. Boeckxstaens GE. Achalasia: virus-induced euthanasia of neurons? Am J Gastroenterol. 2008;103(7):1610-1612.

16. Raymond L, Lach B, Shamji FM. Inflammatory aetiology of primary oesophageal achalasia: an immunohistochemical and ultrastructural study of Auerbach's plexus. Histopathology. 1999;35(5):445-453.

17. Wong RK, Maydonovitch CL, Metz SJ, Baker JR Jr. Significant DQw1 association in achalasia. Dig Dis Sci. 1989;34(3):349-352.

18. Verne GN, Hahn AB, Pineau BC, Hoffman BJ, Wojciechowski BW, Wu WC. Association of HLA-DR and -DQ alleles with idiopathic achalasia. Gastroenterology. 1999;117(1):26-31.

19. Ruiz-de-Leon A, Mendoza J, Sevilla-Mantilla C, et al. Myenteric antiplexus antibodies and class II HLA in achalasia. Dig Dis Sci. 2002;47(1):15-19.

20. Ates F, Vaezi MF. The pathogenesis and management of achalasia current status and future directions. Gut Liver. 2015;9(4):449-463.

21. Gockel I, Bohl JR, Eckardt VF, Junginger T. Reduction of interstitial cells of Cajal (ICC) associated with neuronal nitric oxide synthase (n-NOS) in patients with achalasia. Am J Gastroenterol. 2008;103(4):856-864.

22. Gockel I, Bohl JR, Doostkam S, Eckardt VF, Junginger T. Spectrum of histopathologic findings in patients with achalasia reflects different etiologies. J Gastroenterol Hepatol. 2006;21(4):727-733.

23. Pandolfino JE, Kahrilas PJ, American gastroenterological A. AGA technical review on the clinical use of esophageal manometry. Gastroenterology. 2005;128(1):209-224.

24. Spechler SJ, Castell DO. Classification of oesophageal motility abnormalities. Gut. 2001;49(1):145-151.

25. Salvador R, Costantini M, Zaninotto G, et al. The preoperative manometric pattern predicts the outcome of surgical treatment for esophageal achalasia. J Gastrointest Surg. 2010;14(11):1635-1645

26. Pratap N, Reddy DN. Can achalasia subtyping by high-resolution manometry predict the therapeutic outcome of pneumatic balloon dilatation?: author's reply. J Neurogastroenterol Motil. 2011;17(2):205.

27. de Oliveira JM, Birgisson S, Doinoff C, et al. Timed barium swallow: a simple technique for evaluating esophageal emptying in patients with achalasia. AJR Am J Roentgenol. 1997;169(2):473-479.

28. Vaezi MF, Baker ME, Richter JE. Assessment of esophageal emptying post-pneumatic dilation: use of the timed barium esophagram. Am J Gastroenterol. 1999;94(7):1802-1807.

29. Andersson M, Lundell L, Kostic S, et al. Evaluation of the response to treatment in patients with idiopathic achalasia by the timed barium esophagogram: results from a randomized clinical trial. Dis Esophagus. 2009;22(3):264-273.

30. Tucker HJ, Snape WJ Jr, Cohen S. Achalasia secondary to carcinoma: manometric and clinical features. Ann Intern Med. 1978;89(3): 315-318.

31. Dodds WJ, Stewart ET, Kishk SM, Kahrilas PJ, Hogan WJ. Radiologic amyl nitrite test for distinguishing pseudoachalasia from idiopathic achalasia. AJR Am J Roentgenol. 1986;146(1):21-23.

32. Kahrilas PJ, Kishk SM, Helm JF, Dodds WJ, Harig JM, Hogan WJ. Comparison of pseudoachalasia and achalasia. Am J Med. 1987; 82(3):439-446.

33. Scherer JR, Kwiatek MA, Soper NJ, Pandolfino JE, Kahrilas PJ. Functional esophagogastric junction obstruction with intact peristalsis: a heterogeneous syndrome sometimes akin to achalasia. J Gastrointest Surg. 2009;13(12):2219-2225.

34. Vela MF. Management strategies for achalasia. Neurogastroenterol Motil. 2014;26(9):1215-1221.

35. Vaezi MF, Richter JE. Current therapies for achalasia: comparison and efficacy. J Clin Gastroenterol. 1998;27(1):21-35.

36. Bortolotti M, Mari C, Lopilato C, Porrazzo G, Miglioli M. Effects of sildenafil on esophageal motility of patients with idiopathic achalasia. Gastroenterology. 2000;118(2):253-257.
37. Hoogerwerf WA, Pasricha PJ. Pharmacologic therapy in treating achalasia. Gastrointest Endosc Clin N Am. 2001;11(2):311-324, vii.

38. Annese V, Bassotti G, Coccia G, et al. A multicentre randomised study of intrasphincteric botulinum toxin in patients with oesophageal achalasia. GISMAD Achalasia Study Group. Gut. 2000;46(5):597-600.

39. Patti MG, Feo CV, Arcerito M, et al. Effects of previous treatment on results of laparoscopic Heller myotomy for achalasia. Dig Dis Sci. 1999;44(11):2270-2276.

40. Horgan S, Hudda K, Eubanks T, McAllister J, Pellegrini CA. Does botulinum toxin injection make esophagomyotomy a more difficult operation? Surg Endosc. 1999;13(6):576-579.

41. Smith CD, Stival A, Howell DL, Swafford V. Endoscopic therapy for achalasia before Heller myotomy results in worse outcomes than heller myotomy alone. Ann Surg. 2006;243(5):579-584; discussion 584-586.

42. Kumar AR, Schnoll-Sussman FH, Katz PO. Botulinum toxin and pneumatic dilation in the treatment of achalasia. Tec Gastrointest Endosc. 2014;16(1):10-19.

43. Vaezi MF, Richter JE, Wilcox CM, et al. Botulinum toxin versus pneumatic dilatation in the treatment of achalasia: a randomised trial. Gut. 1999;44(2):231-239.

44. Pasricha PJ, Rai R, Ravich WJ, Hendrix TR, Kalloo AN. Botulinum toxin for achalasia: long-term outcome and predictors of response. Gastroenterology. 1996;110(5):1410-1415.

45. Lambroza A, Schuman RW. Pneumatic dilation for achalasia without fluoroscopic guidance: safety and efficacy. Am J Gastroenterol. 1995;90(8):1226-1229.

46. Thomas V, Harish K, Sunilkumar K. Pneumatic dilation of achalasia cardia under direct endoscopy: the debate continues. Gastrointest Endosc. 2006;63(4):734.

47. Vela MF, Richter JE, Khandwala F, et al. The long-term efficacy of pneumatic dilatation and Heller myotomy for the treatment of achalasia. Clin Gastroenterol Hepatol. 2006;4(5):580-587.

48. Campos GM, Vittinghoff E, Rabl C, et al. Endoscopic and surgical treatments for achalasia: a systematic review and meta-analysis. Ann Surg. 2009;249(1):45-57.

49. Tuset JA, Lujan M, Huguet JM, Canelles P, Medina E. Endoscopic pneumatic balloon dilation in primary achalasia: predictive factors, complications, and long-term follow-up. Dis Esophagus. 2009;22(1): 74-79.

50. Eckardt AJ, Eckardt VF. Current clinical approach to achalasia. World J Gastroenterol. 2009;15(32):3969-3975.

51. Gockel I, Junginger T, Bernhard G, Eckardt VF. Heller myotomy for failed pneumatic dilation in achalasia: how effective is it? Ann Surg. 2004;239(3):371-377.

52. Farhoomand K, Connor JT, Richter JE, Achkar E, Vaezi MF. Predictors of outcome of pneumatic dilation in achalasia. Clin Gastroenterol Hepatol. 2004;2(5):389-394.

53. Eckardt VF, Aignherr C, Bernhard G. Predictors of outcome in patients with achalasia treated by pneumatic dilation. Gastroenterology. 1992;103(6):1732-1738.

54. Eckardt VF, Gockel I, Bernhard G. Pneumatic dilation for achalasia: late results of a prospective follow up investigation. Gut. 2004;53(5): 629-633.

55. Dagli U, Kuran S, Savas N, et al. Factors predicting outcome of balloon dilatation in achalasia. Dig Dis Sci. 2009;54(6):1237-1242.

56. Eckardt VF, Kanzler G, Westermeier T. Complications and their impact after pneumatic dilation for achalasia: prospective long-term follow-up study. Gastrointest Endosc. 1997;45(5):349-353.

57. Metman EH, Lagasse JP, d'Alteroche L, Picon L, Scotto B, Barbieux JP. Risk factors for immediate complications after progressive pneumatic dilation for achalasia. Am J Gastroenterol. 1999;94(5):1179-1185.

58. Vanuytsel T, Lerut T, Coosemans W, et al. Conservative management of esophageal perforations during pneumatic dilation for idiopathic esophageal achalasia. Clin Gastroenterol Hepatol. 2012;10(2):142-149.

59. Richter JE. Update on the management of achalasia: balloons, surgery and drugs. Expert Rev Gastroenterol Hepatol. 2008;2(3):435-445. 
60. Ali A, Pellegrini CA. Laparoscopic myotomy: technique and efficacy in treating achalasia. Gastrointest Endosc Clin N Am. 2001;11(2): 347-358, vii.

61. Richards WO, Torquati A, Holzman MD, et al. Heller myotomy versus Heller myotomy with Dor fundoplication for achalasia: a prospective randomized double-blind clinical trial. Ann Surg. 2004;240(3):405-412; discussion 412-415.

62. Stefanidis D, Richardson W, Farrell TM, et al. SAGES guidelines for the surgical treatment of esophageal achalasia. Surg Endosc. 2012;26(2):296-311.

63. Rawlings A, Soper NJ, Oelschlager B, et al. Laparoscopic Dor versus Toupet fundoplication following Heller myotomy for achalasia: results of a multicenter, prospective, randomized-controlled trial. Surg Endosc. 2012;26(1):18-26.

64. Melvin WS, Needleman BJ, Krause KR, Wolf RK, Michler RE, Ellison EC. Computer-assisted robotic heller myotomy: initial case report. J Laparoendosc Adv Surg Tech A. 2001;11(4):251-253.

65. Sweet MP, Nipomnick I, Gasper WJ, et al. The outcome of laparoscopic Heller myotomy for achalasia is not influenced by the degree of esophageal dilatation. J Gastrointest Surg. 2008;12(1):159-165.

66. Mineo TC, Ambrogi V. Long-term results and quality of life after surgery for oesophageal achalasia: one surgeon's experience. Eur J Cardiothorac Surg. 2004;25(6):1089-1096.

67. Glatz SM, Richardson JD. Esophagectomy for end stage achalasia. J Gastrointest Surg. 2007;11(9):1134-1137.

68. Kadakia SC, Wong RK. Pneumatic balloon dilation for esophageal achalasia. Gastrointest Endosc Clin N Am. 2001;11(2):325-346, vii.

69. Ortega JA, Madureri V, Perez L. Endoscopic myotomy in the treatment of achalasia. Gastrointest Endosc. 1980;26(1):8-10.

70. Pasricha PJ, Hawari R, Ahmed I, et al. Submucosal endoscopic esophageal myotomy: a novel experimental approach for the treatment of achalasia. Endoscopy. 2007;39(9):761-764.

71. Inoue H, Minami H, Kobayashi $\mathrm{Y}$, et al. Peroral endoscopic myotomy (POEM) for esophageal achalasia. Endoscopy. 2010;42(4):265-271.

72. Lujan-Sanchis M, Suarez-Callol P, Monzo-Gallego A, et al. Management of primary achalasia: the role of endoscopy. World J Gastrointest Endosc. 2015;7(6):593-605.

73. von Renteln $\mathrm{D}$, Inoue $\mathrm{H}$, Minami $\mathrm{H}$, et al. Peroral endoscopic myotomy for the treatment of achalasia: a prospective single center study. Am J Gastroenterol. 2012;107(3):411-417.

74. Bhayani NH, Kurian AA, Dunst CM, Sharata AM, Rieder E, Swanstrom LL. A comparative study on comprehensive, objective outcomes of laparoscopic Heller myotomy with per-oral endoscopic myotomy (POEM) for achalasia. Ann Surg. 2014;259(6):1098-1103.

75. Stavropoulos SN, Modayil RJ, Friedel D, Savides T. The International Per Oral Endoscopic Myotomy Survey (IPOEMS): a snapshot of the global POEM experience. Surg Endosc. 2013;27(9):3322-3338.

76. Bechara R, Ikeda H, Inoue H. Peroral endoscopic myotomy: an evolving treatment for achalasia. Nat Rev Gastroenterol Hepatol. 2015;12(7): $410-426$.

77. Stavropoulos SN, Desilets DJ, Fuchs KH, et al. Per-oral endoscopic myotomy white paper summary. Surg Endosc. 2014;28(7):2005-2019.

78. Talukdar R, Inoue H, Reddy DN. Efficacy of peroral endoscopic myotomy (POEM) in the treatment of achalasia: a systematic review and meta-analysis. Surg Endosc. 2015;29(11):3030-3046.
79. Cheng YS, Ma F, Li YD, et al. Temporary self-expanding metallic stents for achalasia: a prospective study with a long-term follow-up. World $J$ Gastroenterol. 2010;16(40):5111-5117.

80. Sharma P, Kozarek R, Practice Parameters Committee of American College of $\mathrm{G}$. Role of esophageal stents in benign and malignant diseases. Am J Gastroenterol. 2010;105(2):258-273; quiz 274.

81. Zhao JG, Li YD, Cheng YS, et al. Long-term safety and outcome of a temporary self-expanding metallic stent for achalasia: a prospective study with a 13-year single-center experience. Eur Radiol. 2009;19(8): 1973-1980.

82. Li YD, Cheng YS, Li MH, Chen NW, Chen WX, Zhao JG. Temporary self-expanding metallic stents and pneumatic dilation for the treatment of achalasia: a prospective study with a long-term follow-up. Dis Esophagus. 2010;23(5):361-367.

83. Moreto M, Ojembarrena E, Barturen A, Casado I. Treatment of achalasia by injection of sclerosant substances: a long-term report. Dig Dis Sci. 2013;58(3):788-796.

84. Niknam R, Mikaeli J, Mehrabi N, et al. Ethanolamine oleate in resistant idiopathic achalasia: a novel therapy. Eur J Gastroenterol Hepatol. 2011;23(12):1111-1115.

85. Richter JE. Esophageal motility disorder achalasia. Curr Opin Otolaryngol Head Neck Surg. 2013;21(6):535-542.

86. Leyden JE, Moss AC, MacMathuna P. Endoscopic pneumatic dilation versus botulinum toxin injection in the management of primary achalasia. Cochrane Database Syst Rev. 2006(4):CD005046.

87. Wang L, Li YM, Li L. Meta-analysis of randomized and controlled treatment trials for achalasia. Dig Dis Sci. 2009;54(11):2303-2311.

88. Mikaeli J, Bishehsari F, Montazeri G, et al. Injection of botulinum toxin before pneumatic dilatation in achalasia treatment: a randomizedcontrolled trial. Aliment Pharmacol Ther. 2006;24(6):983-989.

89. Zhu Q, Liu J, Yang C. Clinical study on combined therapy of botulinum toxin injection and small balloon dilation in patients with esophageal achalasia. Dig Surg. 2009;26(6):493-498.

90. Boeckxstaens G. The European experience of achalasia treatment. Gastroenterol Hepatol (NY). 2011;7(9):609-611.

91. Weber CE, Davis CS, Kramer HJ, Gibbs JT, Robles L, Fisichella PM. Medium and long-term outcomes after pneumatic dilation or laparoscopic Heller myotomy for achalasia: a meta-analysis. Surg Laparosc Endosc Percutan Tech. 2012;22(4):289-296.

92. Pandolfino JE, Kwiatek MA, Nealis T, Bulsiewicz W, Post J, Kahrilas PJ. Achalasia: a new clinically relevant classification by high-resolution manometry. Gastroenterology. 2008;135(5):1526-1533.

93. Rohof WO, Salvador R, Annese V, et al. Outcomes of treatment for achalasia depend on manometric subtype. Gastroenterology. 2013;144(4):718-725; quiz e713-e714.

94. Ghoshal UC, Rangan M. A review of factors predicting outcome of pneumatic dilation in patients with achalasia cardia. J Neurogastroenterol Motil. 2011;17(1):9-13.

95. Boeckxstaens GE, Zaninotto G, Richter JE. Achalasia. Lancet. 2014;383(9911):83-93.

96. Persson J, Johnsson E, Kostic S, Lundell L, Smedh U. Treatment of achalasia with laparoscopic myotomy or pneumatic dilatation: long-term results of a prospective, randomized study. World J Surg. 2015;39(3):713-720.
Clinical and Experimental Gastroenterology

\section{Publish your work in this journal}

Clinical and Experimental Gastroenterology is an international, peerreviewed, open access journal, publishing all aspects of gastroenterology in the clinic and laboratory, including: Pathology, pathophysiology of gastrointestinal disease; Investigation and treatment of gastointestinal disease; Pharmacology of drugs used in the alimentary tract;
Dovepress

Immunology/genetics/genomics related to gastrointestinal disease. This journal is indexed on CAS. The manuscript management system is completely online and includes a very quick and fair peer-review system. Visit http://www.dovepress.com/testimonials.php to read real quotes from published authors. 